\title{
Genomic Alterations In Primary Cardiac Diffuse Large B Cell Lymphoma: A Case Report And Literature Review
}

This article was published in the following Dove Press journal: OncoTargets and Therapy

\author{
Jinjing Zhang' \\ Xuyong Lin $\mathbb{1 D}^{2}$ \\ Yan $\mathrm{Li}^{1}$ \\ Rui Zhang'
}

'Department of Hematology, The First Affiliated Hospital of China Medical University, Shenyang, Liaoning II 000 I, People's Republic of China; ${ }^{2}$ Department of Pathology, The First Affiliated Hospital of China Medical University, Shenyang, Liaoning II000I, People's Republic of China
Correspondence: Rui Zhang Department of Hematology, The First Affiliated Hospital of China Medical University, Shenyang, Liaoning II $000 \mathrm{I}$, People's Republic of China Tel +86-18240200366

Email zhangruicmulh@I63.com

\begin{abstract}
Primary cardiac diffuse large B cell lymphoma (PC-DLBCL) is a rare kind of hematological malignancy, and its clinical and pathologic characteristics, especially in Eastern countries, remain unclear. Moreover, genomic alterations in PC-DLBCL have not been studied previously. We describe a case of a 57-year-old man who presented with exertional dyspnoea due to a heart mass in April 2018 and was diagnosed with PC-DLBCL characterized by immunohistochemical markers of the activated $\mathrm{B}$ cell $(\mathrm{ABC})$ subtype and double expression of c-MYC and Bcl-2. Mutations in a total of 11 genes-TBL1XR1, CD79B, IGLL5, ZMYM3, MYD88, TMSB 4X, PIM1, BTK, NRXN3, CUX1, and CSMD1 - were detected via next-generation sequencing (NGS), while 19 copy number variations (CNVs) such as $1 \mathrm{q}+, 3 \mathrm{p}+, 3 \mathrm{q}+\left({ }^{*} 2\right), 5 \mathrm{p}+, 6 \mathrm{p}-, 6 \mathrm{q}-$, $7 q^{+},+11,12 q^{-}, 15 q^{-}, 17 q^{+}, 17 p^{-},+18,19 q^{+}, 19 p^{-}, 19 q^{-}, X q^{+}$, and $-Y$ and 4 copy-neutral loss of heterozygosity (CN-LOH) lesions located at 1q21.1q44, 3p26.3q11.2, 3q13.11q29 and $6 \mathrm{p} 22.2 \mathrm{p} 21.32$ were identified by single nucleotide polymorphism (SNP) array karyotyping. Some key gene alterations in lymphoma, such as PRDM1 deletion and $B c l-2$ amplification, were identified using SNP array analysis. The patient received 6 courses of chemotherapy (rituximab, cyclophosphamide, doxorubicin, vincristine, prednisone, R-CHOP regimen) after surgery and is currently in remission. In summary, the present case was diagnosed as PCDLBCL, ABC subtype by the Hans algorithm and double expression lymphoma, with cooccurrence of the $M Y D 88^{L 265 P}$ and $C D 79 B$ mutations (MCD) subtype by genetic alteration analysis. This study presents a unique PC-DLBCL case in which complex genomic alterations were revealed by NGS and SNP array analysis, which has never been reported in the literature, and these findings could provide new insight into the genomic characterization of PC-DLBCL. Keywords: primary cardiac diffuse large B cell lymphoma, NGS, SNP array
\end{abstract}

\section{Introduction}

Primary cardiac lymphoma (PCL) is described as extranodal lymphoma involving only the heart and/or pericardium or presenting with cardiac symptoms particularly accompanied by the development of the main mass of the tumour in the heart or pericardium. ${ }^{1}$ PCL is a rare malignant tumour, accounting for $2 \%$ of primary heart tumours and approximately $0.3 \%$ of lymphomas. ${ }^{2,3}$ Across the broad pathologic spectrum of PCL, diffuse large B cell lymphoma (DLBCL) is the most common histologic subtype, accounting for approximately $63-85 \%$ of PCL cases. ${ }^{3,4}$ Recently, genomic aberrations have been regarded to impact the prognosis and outcome of DLBCL; ${ }^{5,6}$ however, the genetic characteristics of primary cardiac diffuse large B cell lymphoma (PC-DLBCL) have rarely been reported..$^{6-10}$ Herein, we report a case of a patient with PC-DLBCL 
and analyse the genomic alterations via next-generation sequencing (NGS) and single nucleotide polymorphism (SNP) array analysis.

\section{Case Presentation}

A 57-year-old male presented with exertional dyspnoea of 1week duration without fever, night sweats and weight loss. He was admitted to the department of cardiac surgery of the First Affiliated Hospital of China Medical University (CMU) in April 2018 because of the right atrial mass revealed by echocardiography in a local hospital with a negative medical history. Physical examination showed no lymphadenopathy, and the liver and spleen were not palpable. Laboratory tests indicated that routine blood parameters, liver and renal function, and the coagulation index were normal, and the patient was negative for anti-HIV antibodies. The electrocardiogram (ECG) revealed sinus tachycardia and atrial premature beats. The computed tomographic angiography (CTA) of the coronary artery demonstrated a low-density bulk in the right atrium with dimensions of $70 \mathrm{~mm}$ X $52 \mathrm{~mm}$ infiltrating into both the superior vena cava (SVC) and inferior vena cava (IVC), oppressing the pulmonary vein (Figure 1). Increased uptake of FDP ( $\mathrm{SUV}=25.8$ ) was shown in the cardiac mass by positron emission tomography/computed tomography (PET/CT), and no extracardiac involvement was demonstrated. The patient underwent surgery for cardiac mass resection, which provided pathologic evidence of DLBCL. The cardiac mass

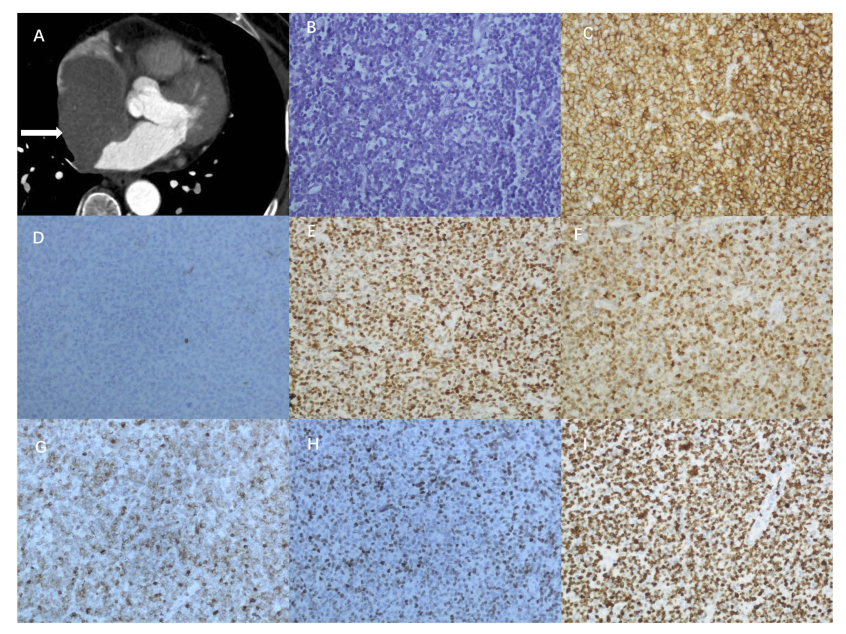

Figure I The radiological and pathological examinations of the patient. (A) Computed tomographic angiography (CTA) of the coronary artery revealed a low-density mass (white arrow) in the right atrium. (B) Microscopic examination showed diffuse infiltration by large lymphoid cells with round or oval nuclei and an altered nuclear-cytoplasmic ratio (original magnification $\times 200$ ). (C-I) Immunohistochemical staining of the lymphoid cells (original magnification $\times 200$ ). (C) Positive staining for CD20. (D) Negative staining for CD 10. (E) Positive staining for Bcl-6. (F) Positive staining for Mum I. (G) Positive staining for Bcl-2. (H) Positive staining for MYC. (I) The Ki67 staining demonstrating a $80 \%$ proliferative rate. was composed of a diffuse infiltrate of large lymphoid cells with round or oval nuclei and an altered nuclear-cytoplasmic ratio, as observed under microscopic examination. Immunohistochemical staining revealed that the lymphoid cells were positive for CD20, CD45, Pax-5, Bcl-6, Mum1, Bcl-2, and MYC; sporadic positive for CD21 and CD3; and negative for CD10, CK, CyclinD1, CD30, and CD5. The Ki67 index was $80 \%$ (Figure 1). Using a NGS platform (Hiseq X Ten, Illumina, San Diego, CA), the whole exome sequencing of 165 hematological tumour-associated genes (Table S1) was performed at Righton Biomedical technology Company Limited (Shanghai, China) using tumour DNA extracted from formalin-fixed paraffin-embedded (FFPE) block. The original data reads obtained from sequencing libraries were collated and evaluated according to the standard protocols, compared with the reference sequence (CRCh37/UCSC hg19), and the sequencing depth and coverage were counted. SNP and InDel mutation information were detected. Functional annotation (GO, Pathway) and conservative prediction and pathogenicity analysis (SIFT, Polyphen-2, GERP) of the mutation genes were performed. In order to get more detailed information, we screened the oncogene/suppressor gene/susceptible gene, analyzed the high-frequency mutation gene, as well as the mutation characteristics and frequency of NMF, and screened the known driving genes. A total of 13 point mutations involving 11 genes were demonstrated by NGS. Seven point mutations in TBL1XR1, CD79B, IGLL5, ZMYM3, MYD88, TMSB4X and PIM1 had previously been reported in DLBCL, while six point mutations in PIM1, BTK, $N R X N 3, C U X 1$ and $C S M D 1$ were first reported in lymphoma. Detailed information on the gene mutated is provided in Table 1. DNA copy number variations (CNVs) and regions of homozygosity were identified using whole-genome hybridization at Kingmed Clinical Laboratory (Guangzhou, China). and the genomic locations were retrieved from the National Center for Biotechnology Information (NCBI) build 37 (hg 19) genome. Tumour DNA extracted from FFPE sample using Qiagen QIAamp DNA FFPE Tissue Kit (Qiagen Inc., Valencia, CA) was hybridized with the OncoScan CNV FFPE assay kit (Affymetrix, Santa Clara, CA, USA) according to the manufacturer's protocols. Copy number analysis was estimated utilizing the Chromosome Analysis Suite 3.0 (ChAS 3.0) software, which enabled us to view and summarize chromosomal aberrations across the genome including copy number gain or loss, or loss of heterozygosity. In total, $19 \mathrm{CNVs}$ involving 13 chromosomes $(1,3,5,6,7,11,12,15,17,18,19$, $\mathrm{X}$, and $\mathrm{Y}$ ), including 11 chromosomal gain and eight chromosomal loss CNVs, and four copy-neutral loss of heterozygosity 
Table I Gene Mutations Revealed By Next-Generation Sequencing (NGS)

\begin{tabular}{|c|c|c|c|}
\hline Gene & $\begin{array}{l}\text { Location Mutation } \\
\text { Consequence }\end{array}$ & VAF & Significance In Lymphoma \\
\hline$T B L I X R I$ & $\begin{array}{l}\text { exon } 13 \text { c.AlI84G } \\
\text { Y395C }\end{array}$ & $82 \%$ & $\begin{array}{l}\text { Occurred in PCNSL, ABC DLBCL and } 18 \% \text { of OMZL cases; may be involved in the occurrence of } \\
\text { lymphoma and associated with resistance to glucocorticoids in B-ALL. }\end{array}$ \\
\hline$C D 79 B$ & exon 5 c.A587C Y196S & $38 \%$ & $\begin{array}{l}\text { Occurred in } 25 \% \text { of ABC DLBCL cases but not in other subtypes of DLBCL or Burkitt lymphoma; } \\
\text { BTK, SYK and PKC inhibitors might be effective. }\end{array}$ \\
\hline IGLL5 & $\begin{array}{l}\text { exon } 2 \text { c.299_3I Idel: p. } \\
\text { GI00fs }\end{array}$ & $31 \%$ & Occurred in SBP, DLBCL and CLL. \\
\hline ZMYM3 & $\begin{array}{l}\text { exon } 25 \text { c.G3998A } \\
\text { WI } 333 X\end{array}$ & $80 \%$ & $\begin{array}{l}\text { An epigenetic regulatory gene and chromatin modification factor; might be correlated with the } \\
\text { formation of lymphoma. }\end{array}$ \\
\hline MYD88 & exon 5 c.T794C L265P & $89 \%$ & $\begin{array}{l}\text { Occurred in } L P L \text { and } 29 \% \text { of } A B C \text { DLBCL cases but not in other subtypes of DLBCL or Burkitt } \\
\text { lymphoma; IRAKI/4 inhibitors might be effective. }\end{array}$ \\
\hline TMSB4X & exon 3 c.CII8T Q40X & $65 \%$ & Occurred in relapsed DLBCL and might be associated with poor outcome. \\
\hline \multirow[t]{3}{*}{ PIMI } & exon 4 c.G529A VI77M & $44 \%$ & \multirow{3}{*}{$\begin{array}{l}\text { PIMI mutations reduced ibrutinib sensitivity in } A B C-D L B C L \text { through increasing PIMI protein } \\
\text { stability. }\end{array}$} \\
\hline & exon I c.T347C LII6P* & $38 \%$ & \\
\hline & $\begin{array}{l}\text { exon } 253 \text { c.G55088C } \\
\text { GI8363A* }\end{array}$ & $41 \%$ & \\
\hline BTK & exon 4 c.G388A EI 30K* & $42 \%$ & $\begin{array}{l}\text { Occurred in B-cell lymphomas such as CLL, DLBCL, MCL, and WM. C48IS mutation was } \\
\text { associated with resistance to ibrutinib. }\end{array}$ \\
\hline NRXN3 & $\begin{array}{l}\text { exon } 17 \text { c.C298IA } \\
\text { A994D* }\end{array}$ & $32 \%$ & NRXN gene mutation occurred in DLBCL. \\
\hline CUXI & $\begin{array}{l}\text { exon } 16 \text { c.CI927A } \\
\text { Q643K* }\end{array}$ & $74 \%$ & Truncation mutation or loss of the CUXI gene was related to poor prognosis. \\
\hline CSMDI & $\begin{array}{l}\text { exon } 3 \text { c.C5546T } \\
\text { TI849M* }\end{array}$ & $38 \%$ & CSMDI gene mutation may be associated with treatment-related AML. \\
\hline
\end{tabular}

Notes: *The detected point mutation was not reported to be related to haematological malignancy in the COSMIC database or the literature.

Abbreviations: VAF, variant allele frequency; PCNSL, primary central nervous system lymphoma; ABC DLBCL, activated B-cell diffuse large B-cell lymphoma; OMZL, ocular marginal zone lymphoma; B-ALL, B cell acute lymphoblastic leukaemia; BTK, Bruton tyrosine kinase; SYK, spleen tyrosine kinase; PKC, protein kinase C; SPB, solitary bone plasmacytoma; CLL, chronic lymphocytic leukaemia; LPL, diffuse large B-cell lymphoma; IRAKI/4, interleukin I receptor-associated kinase I/4; MCL, mantle cell lymphoma; WM, Waldenström macroglobulinemia; AML, acute myeloid leukaemia.

(CN-LOH) lesions were identified by SNP array karyotyping (Figure 2). Sixteen large chromosomal abnormalities with sizes greater than $5 \mathrm{Mb}$ were observed with multiple chromosome involvement, for example, $1 \mathrm{q}+, 3 \mathrm{p}+, 3 \mathrm{q}+5 \mathrm{p}+, 6 \mathrm{p}-, 6 \mathrm{q}-$, $7 \mathrm{q}^{+},+11,15 \mathrm{q}-, 17 \mathrm{q}^{+},+18,19 \mathrm{q}+, \mathrm{Xq}+$ and $-\mathrm{Y}$. Four cryptic chromosomal aberrations $(\leq 5 \mathrm{Mb})$, all of which were chromosomal loss, were recognized at $12 \mathrm{q} 24.31,17 \mathrm{p} 13.1,19 \mathrm{p} 13.3$ and $19 \mathrm{q} 13.42 \mathrm{q} 13.43$. It is worth noting that some cancerassociated genes were located in these regions of genomic imbalance, for example, the tumour suppressor genes (TSGs) PRDM1 (6q21), TP53 (17p13.1), HLA-A, HLA-B, and HLA-C (6q22.1, 6q22.3, and 6q22.3, respectively) and the oncogenes
Bcl-2 (18q21.3), Bcl-6 (3q27.3), and SPIB (19q33.33) (Table 2). In addition, using TP53/CSP17 Probe kit (17p13.1/17p11.1-q11) (Jinpujia medical technology Company Limited, Beijing, China), the deletion of $17 \mathrm{p} 13.1$ containing TP53 gene was confirmed by Fluorescence in situ hybridization (FISH) (Figure S1) which was in accordance with SNP array. The patient received 6 courses of chemotherapy (rituximab, cyclophosphamide, doxorubicin, vincristine, prednisone, R-CHOP regimen) after surgery, achieved complete remission as evaluated by PET/CT and showed normal cardiac function by echocardiography. $\mathrm{He}$ is currently in remission as of July 2019. 


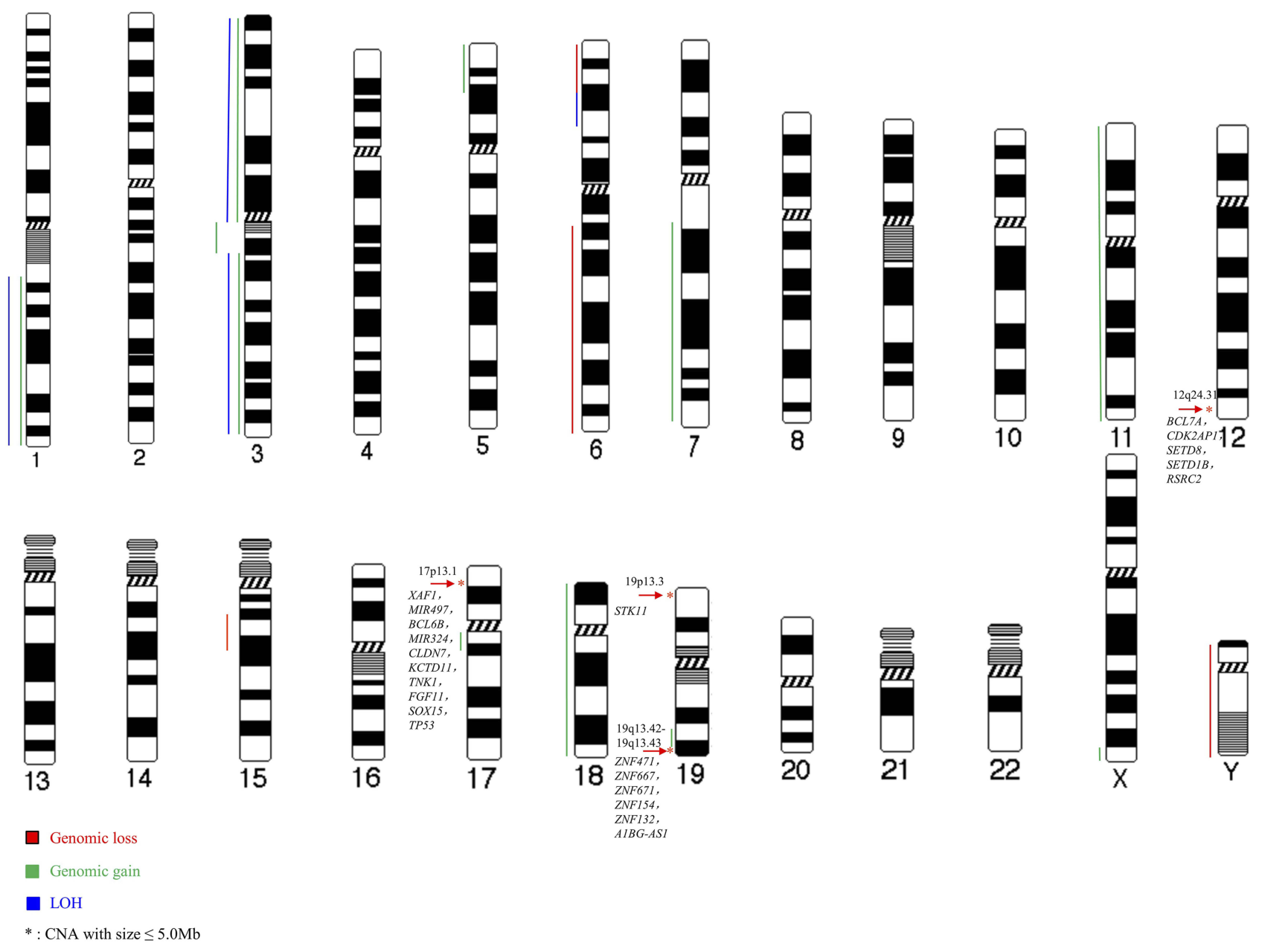

Figure 2 Copy number variations in the present case of primary cardiac diffuse large B cell lymphoma. Four cryptic chromosomal aberrations ( $\leq 5 \mathrm{Mb})$, all of which were chromosomal loss, were recognized at $12 q 24.31$, 17 p 13.1 , $19 p / 3.3$ and $19 q 13.42 q 13.43$ and harbored interesting genes.

\section{Discussion And Conclusions}

Here, we report a case of DLBCL with a cardiac mass as the initial manifestation. DLBCL is a highly heterogeneous hematological tumour at the clinical, immunohistochemical and genetic levels. DLBCL is divided into germinal center B cell (GCB) and activated B cell (ABC) subtypes according to immunohistochemical markers. In addition, it can be classified into double-hit or double-expression lymphoma based on the rearrangement and expression of MYC and either Bcl2 or Bcl- $6 .{ }^{11}$ Differentiation between the subtypes is important for clinical procedures because it informs the treatment decisions for and prognostic evaluation of DLBCL. ${ }^{5}$ In addition, the unique location of the tumour as well as the underlying genomic aberrations are highlighted in the 2016 revised WHO classification of lymphoid tumours. ${ }^{12}$ Some novel separate entities of DLBCL, such as primary cutaneous DLBCL, leg type and high-grade B-cell lymphoma, are defined according to their distinct prognosis. ${ }^{12}$ Therefore, as PC-DLBCL is an extremely rare subset of extranodal lymphomas, it is worthwhile to investigate the clinical outcome and genomic aberrations of this malignancy.

Since it was defined as a distinct pathological categorization in $1978,{ }^{1}$ PCL has been increasingly addressed either in single case reports or in literature reviews. ${ }^{1,4,7-10}$ However, few studies have investigated both the clinical and pathologic characteristics of PC-DLBCL, especially in Eastern countries. Literatures were searched using "primary cardiac lymphoma" or "cardiac" or "lymphoma" in the databases of "Pubmed", "China National Knowledge Infrastructure", "Wanfang" and "Weipu". Therefore, including the present case, a total of 14 cases of PC-DLBCL diagnosed from 1986 to 2018 in China and analysed with the Hans algorithm were reviewed in this study ${ }^{13}$ (Table 3 ). Our review showed that cases of PC-DLBCL more frequently occur in older, male patients (median age: 57 years, male: female=1.33:1), accompanied by poor prognostic factors such as cardiac 
Table 2 Findings Of Single Nucleotide Polymorphism (SNP) Array Karyotyping Analysis

\begin{tabular}{|c|c|c|c|c|c|}
\hline \multirow{2}{*}{$\begin{array}{l}\text { Chromosome } \\
\text { Region }\end{array}$} & \multirow{2}{*}{$\begin{array}{l}\text { Genomic Coordinates } \\
\text { (NCBI Build 37) }\end{array}$} & \multicolumn{3}{|c|}{ Size (Mb) } & \multirow[t]{2}{*}{ Interesting Genes } \\
\hline & & Gain & Loss & LOH & \\
\hline Iq2 I. Iq44 & $|44,009,053 \rightarrow 249,2| 2,878$ & 105.20 & & 105.20 & BTG2, IRFZBP2, PCNX2 \\
\hline $3 p 26.3 q 11.2$ & $63,4 I I \rightarrow 96,922,673$ & 96.86 & & 96.86 & ROBO2, FANCD2, IRAK2 \\
\hline $3 q|1.2 q| 3.11$ & $96,922,673 \rightarrow 103,136,123$ & 6.21 & & & NFKBI2 \\
\hline $3 q 13.11 q 29$ & $103,136,123 \rightarrow 197,852,564$ & 94.72 & & 94.72 & BCL6, PIK3CA, KLHL6, TP63 \\
\hline $5 p|5.33 p| 4.3$ & $38,139 \rightarrow 20,054,865$ & 20.02 & & & $N / A$ \\
\hline $6 p 25.3 p 22.2$ & $204,909 \rightarrow 26,205,293$ & & 26.00 & & FOXCI, HIVEPI, ID4*,JARID2*,NOL7*,DUSP22*,CASCI5* \\
\hline $6 p 22.2 p 21.32$ & $26,205,293 \rightarrow 32,202,678$ & & & 6.00 & TRIM27*,MHC class I gene* \\
\hline $6 q 14.1 q 27$ & $82,029,|109 \rightarrow| 70,9|3,05|$ & & 88.88 & & $\begin{array}{l}\text { HLA-A, HLA-B, HLA-C, BACH2, CASP8AP2, PRDMI, TNFAIP3 } \\
\text { (A20), MAP3K5, ARIDIB }\end{array}$ \\
\hline $7 q 11.23 q 36.3$ & $75,328,9|4 \rightarrow| 56,548,645$ & 81.22 & & & $C D K / 4$ \\
\hline I lpterqter & $I \rightarrow \mid 35,086,622$ & 135.09 & & & FGF4, CCNDI, LOC283I77 \\
\hline $12 q 24.31$ & $|2|, 738,24|\rightarrow| 23,989,250$ & & 2.25 & & SETDIB, BCL7A*, CDK2API*, SETD8*, SETDIB*, RSRC2* \\
\hline $15 q \mid 4 q 21.2$ & $36, \mid 20,789 \rightarrow 5 I, 472,245$ & & 15.35 & & TP53BPI, B2M,SPREDI \\
\hline$|7 p| 3.1$ & $6,567,190 \rightarrow 8,354,833$ & & 1.79 & & $\begin{array}{l}\text { TP53, XAFI*, MIR497*, BCL6B*, MIR324*, CLDN7*, KCTDII*, } \\
\text { TNKI*, FGFII*, SOXI5* }\end{array}$ \\
\hline$|7 q| 1 .|q| 2$ & $25,326,94 I \rightarrow 34,477,480$ & 81.22 & & & $N / A$ \\
\hline 18 pterqter & $\mathrm{I} \rightarrow 80,373,285$ & 80.37 & & & $B C L-2, M A L T I$ \\
\hline $19 p \mid 3.3$ & $247,232 \rightarrow 1,362,613$ & & 1.12 & & TNFSF7(CD70), TNFSF9, STKII* \\
\hline $19 q 13.33 q 13.42$ & $49,5 \mathrm{I} 3,273 \rightarrow 56,026,072$ & 6.51 & & & PRMTI, BCL2LI2, SPIB \\
\hline $19 q \mid 3.42 q 13.43$ & $56,026,072 \rightarrow 59,093,239$ & & 3.07 & & ZNF47I*, ZNF667*, ZNF67I*, ZNFI54*, ZNFI32*, AIBG-ASI* \\
\hline $\mathrm{Xq28}$ & $|48,258| ,48 \rightarrow|55,2| 9,364$ & 6.96 & & & $N / A$ \\
\hline Y pterqter & $I \rightarrow 57,227,4 \mathrm{I} 5$ & & 57.23 & & $N / A$ \\
\hline
\end{tabular}

Notes: *The interesting genes were not found to be reported related with DLBCL in literatures.

bulk and increased levels of lactate dehydrogenase (LDH), and no bone marrow involvement. The clinical features are consistent with those identified in a previous PC-DLBCL study in Western countries, except that Chinese patients seem to be younger than patients in Western countries. ${ }^{4}$ The tumour cells more frequently originated from the postgerminal center and were characterized by high proliferative activity (a higher Ki67 index and double expression of c-MYC and BCL2/BCL6). Both the ABC subtype and double expression of c-MYC and BCL2/BCL6 have been identified as markers of poor prognosis in DLBCL. ${ }^{11,14}$ There was no uniform recommendation on PC-DLBCL treatment. Surgery, radiotherapy and chemotherapy are the major therapeutic strategies currently reported. Statistical analysis of treatment efficacy and survival in PC-DLBCL was lacking because of the rarity of this disease. ${ }^{4}$

Genomic aberrations provide clues on the causes underlying the poor outcome of PC-DLBCL; however, these findings have not been reported in previous studies. Due to the limitations of traditional cytogenetic studies (such as G-banding analysis) in biopsy samples, it is difficult to describe the compendium of chromosomal changes in lymphoma. Recently, SNP array analysis has been recommended to identify whole-genome aberrations in lymphoma, including CNVs as well as CN-LOH lesions. ${ }^{15,16}$ This method revealed the complex karyotype in the present case, including 
Table 3 The Clinical And Pathological Features Of I4 PCDLBCLs With Hans Algorithm In China

\begin{tabular}{|c|c|c|}
\hline Parameters & Subgroup & $\begin{array}{l}\text { Case } \\
\text { Number }\end{array}$ \\
\hline $\begin{array}{l}\text { Age (years old) at } \\
\text { diagnosis }\end{array}$ & $\begin{array}{l}>60 \\
\leq 60\end{array}$ & $\begin{array}{l}6 \\
8\end{array}$ \\
\hline Gender & $\begin{array}{l}\text { Male } \\
\text { Female }\end{array}$ & $\begin{array}{l}8 \\
6\end{array}$ \\
\hline Size of cardiac mass & $\begin{array}{l}\geq 6 \mathrm{~cm} \\
<6 \mathrm{~cm} \\
N / A\end{array}$ & $\begin{array}{l}8 \\
3 \\
3\end{array}$ \\
\hline $\begin{array}{l}\text { Bone marrow } \\
\text { involvement }\end{array}$ & $\begin{array}{l}\text { Yes } \\
\text { No } \\
\text { N/A }\end{array}$ & $\begin{array}{l}0 \\
7 \\
7\end{array}$ \\
\hline LDH level>normal & $\begin{array}{l}\text { Yes } \\
\text { No } \\
\text { N/A }\end{array}$ & $\begin{array}{l}8 \\
0 \\
6\end{array}$ \\
\hline Pathological subtype & $\begin{array}{l}\mathrm{GCB} \\
\mathrm{ABC}\end{array}$ & $\begin{array}{l}4 \\
10\end{array}$ \\
\hline Ki67 & $\begin{array}{l}\geq 70 \% \\
<70 \% \\
\text { N/A }\end{array}$ & $\begin{array}{l}10 \\
1 \\
3\end{array}$ \\
\hline c-Myc expression & $\begin{array}{l}\text { Positive } \\
\text { Negative } \\
\text { N/A }\end{array}$ & $\begin{array}{l}4 \\
0 \\
10\end{array}$ \\
\hline BCL2 expression & $\begin{array}{l}\text { Positive } \\
\text { Negative } \\
\text { N/A }\end{array}$ & $\begin{array}{l}8 \\
3 \\
3\end{array}$ \\
\hline BCL6 expression & $\begin{array}{l}\text { Positive } \\
\text { Negative } \\
\text { N/A }\end{array}$ & $\begin{array}{l}7 \\
5 \\
2\end{array}$ \\
\hline Double expression & $\begin{array}{l}\text { Yes } \\
\text { No } \\
\text { N/A }\end{array}$ & $\begin{array}{l}4 \\
0 \\
10\end{array}$ \\
\hline Surgical resection & $\begin{array}{l}\text { Yes } \\
\text { No } \\
\text { Orthotopic heart } \\
\text { transplantation }\end{array}$ & $\begin{array}{l}8 \\
4 \\
2\end{array}$ \\
\hline Chemotherapy & $\begin{array}{l}\text { Yes } \\
\text { No }\end{array}$ & $\begin{array}{l}11 \\
3\end{array}$ \\
\hline
\end{tabular}

the $1 \mathrm{q}+, 3 \mathrm{q}+, 6 \mathrm{q}-, 7 \mathrm{q}-$ and $17 \mathrm{p}-\mathrm{CNVs}$, which have been reported in DLBCLs. Cryptic chromosomal losses rather than chromosomal gains were demonstrated by SNP array analysis. The set of affected genes included crucial tumour suppressor genes (TSGs) in lymphomas, such as TP53, SETD1B, TNFSF9 and TNFSF7 (CD 70). ${ }^{5,17}$ Moreover, the analysis revealed unique $\mathrm{CNVs}$ that have been mentioned in previous studies but are of interest. For example, amplification of SPIB (19q33.33), inactivation of PRDMI (6q21), and loss of HLA-A, HLA-B, and HLA-C have been shown to be highly associated with the MCD (based on the co-occurrence of the $M Y D 88^{L 265 P}$ and $C D 79 B$ mutations) genetic subtype of DLBCL. ${ }^{6}$ Candidate oncogenes and TSGs located in the $\mathrm{CNV}$ and $\mathrm{LOH}$ regions according to the previous literature are listed in Table $2 .{ }^{6,17-20}$ It is worth noting that this case had copy number gains in $B c l-6$ and $B c l-2$, which was the underlying mechanism for the dual expression of Bcl-6 and Bcl-2.

In recent years, genomic sequencing studies focusing on DLBCL have been performed, revealing the genetic mechanisms of lymphomagenesis, highlighting the molecular heterogeneity of the subtypes and identifying somatic mutations with therapeutic and prognostic effects, which will likely offer potential precision-medicine strategies in DLBCL. 5,6,18,19,21,22 Twelve gene mutations contributing to lymphoma transformation and progression were identified in this study. Both the MYD88 and CD79B mutations could be classified into the MCD genetic subtype; $96 \%$ of patients with this subtype have $\mathrm{ABC}$ subgroup $\mathrm{DLBCL}^{6}$ and show a trend of extranodal involvement, such as that in primary central nervous system lymphoma (PCNSL). ${ }^{23}$ In addition, mutations in CD79B, MYD88, and TBL1XR1 leading to abnormal NF$\mathrm{kB}$ signalling activation may result in the lymphomagenesis of PC-DLBCL and serve as therapeutic targets. ${ }^{6}$ The novel targeted therapy drugs, including inhibitors of BTK, SYK, PKC, IRAK1/4 and PIM, could be replacement selections. $^{24-27}$

\section{Conclusion}

In summary, an integrated genomic evaluation procedure was adopted here to delineate the whole-genome abnormalities in a rare case of PC-DLBCL. The present case was diagnosed as PC-DLBCL, ABC subtype by the Hans algorithm and double expression lymphoma, MCD subtype by genetic alteration analysis. Although the patient acquired complete remission with chemotherapy, further follow-up is needed to reveal the influence of genomic aberrations on long-term survival. To our knowledge, the present case is unique because the use of whole exome sequencing and SNP array analysis to detect the genetic features of PC-DLBCL has not been reported to date. The results of our molecular examination provide new insights into the genomic characterization of PC-DLBCL. 


\section{Abbreviations}

$\mathrm{ABC}$, activated B-cell; CTA, computed tomographic angiography; CNVs, copy number variations; $\mathrm{CN}-\mathrm{LOH}$, copy-neutral loss of heterozygosity; ChAS, Chromosome Analysis Suite; ECG, electrocardiogram; FFPE, formalinfixed paraffin-embedded; FISH, fluorescence in situ hybridization; GCB, germinal center B cell; IVC, inferior vena cava; LDH, lactate dehydrogenase; $\mathrm{MCD}$, the co-occurrence of the $M Y D 88^{L 265 P}$ and $C D 79 B$ mutations; NGS, next-generation sequencing; PC-DLBCL, Primary cardiac diffuse large B cell lymphoma; PCL, Primary cardiac lymphoma; PET/CT, positron emission tomography/computed tomography; PCNSL, primary central nervous system lymphoma; R-CHOP, rituximab, cyclophosphamide, doxorubicin, vincristine, prednisone; SNP, single nucleotide polymorphism; SVC, superior vena cava; TSGs, tumour suppressor genes.

\section{Ethical Approval}

Written informed consent to have the case details published was obtained from the patient, and the study was approved by Ethics Committee of the First Affiliated Hospital of China Medical University.

\section{Acknowledgement}

This work was supported by the National Natural Science Foundation of China (grant number: 81600117).

\section{Disclosure}

The authors declare that they have no competing interests in this work.

\section{References}

1. Petrich A, Cho SI, Billett H. Primary cardiac lymphoma: an analysis of presentation, treatment, and outcome patterns. Cancer. 2011;117 (3):581-589. doi:10.1002/cncr.25444

2. Hudzik B, Miszalski-Jamka K, Glowacki J, et al. Malignant tumors of the heart. Cancer Epidemiol. 2015;39(5):665-672. doi:10.1016/j. canep.2015.07.007

3. Oliveira GH, Al-Kindi SG, Hoimes C, Park SJ. Characteristics and survival of malignant cardiac tumors: a 40-year analysis of $>500$ patients. Circulation. 2015;132(25):2395-2402. doi:10.1161/ CIRCULATIONAHA.115.016418

4. Carras S, Berger F, Chalabreysse L, et al. Primary cardiac lymphoma: diagnosis, treatment and outcome in a modern series. Hematol Oncol. 2017;35(4):510-519. doi:10.1002/hon.2301

5. Chapuy B, Stewart C, Dunford AJ, et al. Molecular subtypes of diffuse large B cell lymphoma are associated with distinct pathogenic mechanisms and outcomes. Nat Med. 2018;24(5):679-690. doi:10.1038/ s41591-018-0016-8
6. Schmitz R, Wright GW, Huang DW, et al. Genetics and pathogenesis of diffuse large B-cell lymphoma. $N$ Engl J Med. 2018;378 (15):1396-1407. doi:10.1056/NEJMoa1801445

7. Perrone MA, Intorcia A, Morgagni R, et al. Primary cardiac lymphoma: the role of multimodality imaging. $J$ Cardiovasc Med (Hagerstown). 2018;19(8):455-458. doi:10.2459/JCM.00000000000 00668

8. Pistritto AM, Pavo N, Maurer G, Binder T, Goliasch G. Multimodality imaging of a primary cardiac diffuse large B-cell lymphoma. Eur Heart J Cardiovasc Imaging. 2015;16(8):909. doi:10. 1093/ehjci/jev099

9. Soon G, Ow GW, Chan HL, Ng SB, Wang S. Primary cardiac diffuse large B-cell lymphoma in immunocompetent patients: clinical, histologic, immunophenotypic, and genotypic features of 3 cases. Ann Diagn Pathol. 2016;24:40-46. doi:10.1016/j.anndiagpath.2016.05. 005

10. Wan Y, He D, Ye Y, et al. Primary cardiac diffuse large B-cell lymphoma with concurrent high MYC and BCL2 expression in an immunocompetent Chinese elderly woman. Cardiovasc Pathol. 2017;31:54-56. doi:10.1016/j.carpath.2017.07.006

11. Menguy S, Frison E, Prochazkova-Carlotti M, et al. Double-hit or dual expression of MYC and BCL2 in primary cutaneous large B-cell lymphomas. Mod Pathol. 2018;31(8):1332-1342. doi:10.1038/s41 379-018-0041-7

12. Swerdlow SH, Campo E, Pileri SA, et al. The 2016 revision of the World Health Organization classification of lymphoid neoplasms. Blood. 2016;127(20):2375-2390. doi:10.1182/blood-2016-01-643569

13. Zhang JJ, Zhang R, Li Y. Clinical characteristics of 37 cases of primary cardiac diffuse large B-cell lymphoma in China. Oncol Prog. 2019;17 (18):2167-2171. doi:10.11877/j.issn.1672-1535.2019.17.18.17

14. Staiger AM, Ziepert M, Horn H, et al. Clinical impact of the cell-oforigin classification and the MYC/BCL2 dual expresser status in diffuse large B-cell lymphoma treated within prospective clinical trials of the german high-grade non-hodgkin's lymphoma study group. J Clin Oncol. 2017;35(22):2515-2526. doi:10.1200/JCO.20 16.70 .3660

15. Pasqualucci L, Trifonov V, Fabbri G, et al. Analysis of the coding genome of diffuse large B-cell lymphoma. Nat Genet. 2011;43 (9):830-837. doi:10.1038/ng.892

16. Scholtysik R, Kreuz M, Hummel M, et al. Characterization of genomic imbalances in diffuse large B-cell lymphoma by detailed SNPchip analysis. Int J Cancer. 2015;136(5):1033-1042. doi:10.1002/ ijc. 29072

17. Etebari M, Navari M, Piccaluga PP. SNPs array karyotyping in nonhodgkin lymphoma. Microarrays (Basel). 2015;4(4):551-569. doi:10.3390/microarrays4040551

18. Novak AJ, Asmann YW, Maurer MJ, et al. Whole-exome analysis reveals novel somatic genomic alterations associated with outcome in immunochemotherapy-treated diffuse large B-cell lymphoma. Blood Cancer J. 2015;5:e346. doi:10.1038/bcj.2015.69

19. Mareschal S, Dubois S, Viailly P-J, et al. Whole exome sequencing of relapsed/refractory patients expands the repertoire of somatic mutations in diffuse large B-cell lymphoma. Genes Chromosomes Cancer. 2016;55(3):251-267. doi:10.1002/gcc.22328

20. Trifonov V, Pasqualucci L, Dalla Favera R, Rabadan R. MutComFocal: an integrative approach to identifying recurrent and focal genomic alterations in tumor samples. BMC Syst Biol. 2013;7:25. doi:10.1186/ 1752-0509-7-25

21. de Miranda NFCC, Georgiou K, Chen L, et al. Exome sequencing reveals novel mutation targets in diffuse large B-cell lymphomas derived from Chinese patients. Blood. 2014;124(16):2544-2553. doi:10.1182/blood-2013-12-546309

22. Dubois S, Viailly P-J, Mareschal S, et al. Next-generation sequencing in diffuse large B-cell lymphoma highlights molecular divergence and therapeutic opportunities: a LYSA study. Clin Cancer Res. 2016;22(12):2919-2928. doi:10.1158/1078-0432.CCR-15-2305 
23. Grommes C, Pastore A, Palaskas N, et al. Ibrutinib unmasks critical role of bruton tyrosine kinase in primary CNS lymphoma. Cancer Discov. 2017;7(9):1018-1029. doi:10.1158/2159-8290.CD-17-0613

24. Scott JS, Degorce SL, Anjum R, et al. Discovery and optimization of pyrrolopyrimidine inhibitors of interleukin-1 receptor associated kinase 4 (IRAK4) for the treatment of mutant MYD88L265P diffuse large B-cell lymphoma. J Med Chem. 2017;60(24):10071-10091. doi:10.1021/acs.jmedchem.7b01290

25. Lionakis MS, Dunleavy K, Roschewski M, et al. Inhibition of B cell receptor signaling by ibrutinib in primary CNS lymphoma. Cancer Cell. 2017;31(6):833-843.e5. doi:10.1016/j.ccell.2017.04.012
26. Kuo H-P, Ezell SA, Hsieh S, et al. The role of PIM1 in the ibrutinibresistant ABC subtype of diffuse large B-cell lymphoma. Am J Cancer Res. 2016;6(11):2489-2501.

27. Younes A, Ansell S, Fowler N, et al. The landscape of new drugs in lymphoma. Nat Rev Clin Oncol. 2017;14(6):335-346. doi:10.1038/ nrclinonc.2016.205

\section{Publish your work in this journal}

OncoTargets and Therapy is an international, peer-reviewed, open access journal focusing on the pathological basis of all cancers, potential targets for therapy and treatment protocols employed to improve the management of cancer patients. The journal also focuses on the impact of management programs and new therapeutic

Submit your manuscript here: https://www.dovepress.com/oncotargets-and-therapy-journal agents and protocols on patient perspectives such as quality of life, adherence and satisfaction. The manuscript management system is completely online and includes a very quick and fair peer-review system, which is all easy to use. Visit http://www.dovepress.com/ testimonials.php to read real quotes from published authors. 